SECTION 19. Management. Marketing. Public administration.

Tatiana Vitalievna Butova Deputy Dean of the faculty of Public and municipal administration, Candidate of Economic Science, Docent Financial University under the Government of the Russian
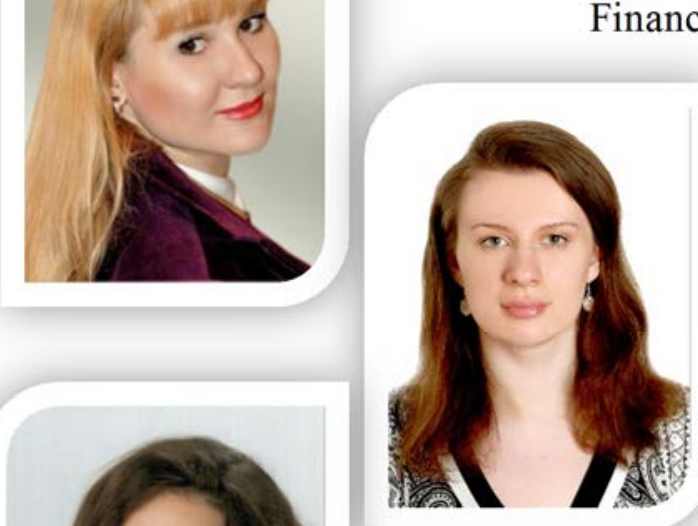

Marina Konstantinovna Krivtsova the third year student, bachelor, the Chairman of Scientific Student Society of the faculty of Public and municipal administration at the Financial

University under the Government of the

Russian Federation marinstar@bk.ru

Daria Evgenievna Petrova the student of the faculty of International economic relations at the Financial University under the Government of the Russian

Federation tvbutova@mail.ru

\title{
THE CHARACTERISTIC OF THE ORGANIZATION OF DEVELOPMENT OF CONSUMERS' MARKET IN MUNICIPAL ENTITIES IN FOREIGN COUNTRIES
}

Abstract: In this work the characteristic of the organization of development of consumers' market in municipal entities on the example of foreign countries is given. The detailed analysis of the structure and priorities of development of consumers' market in Great Britain and its comparison with the main indicators which are used for defining of a level of development of consumers' market in Germany, Austria, France and other foreign countries is carried out.

Key words: consumer market, priorities of development, London, production, municipality, human services.

\section{ХАРАКТЕРИСТИКА ОРГАНИЗАЦИИ РАЗВИТИЯ ПОТРЕБИТЕЛЬСКОГО РЫНКА В МУНИЦИПАЛЬНЫХ ОБРАЗОВАНИЯХ ЗАРУБЕЖНЫХ СТРАН}

Аннотация: В данной работе дается характеристика организации развития потребительского рынка в муниципальных образованиях на примере зарубежных стран. Проводится детальный анализ структурь и приоритетов развития потребительского рынка Великобритании и сравнение с основными показателями, применяющимися для определения уровня развития потребительского рынка Германии, Австрии, Франции и других зарубежных стран.

Ключевые слова: потребительский рынок, приоритеты развития, Лондон, продукция, муниципальное образование, сфера услуг.

Научным сообществом зарубежных стран признано, что потребительский рынок является одним из важных индикаторов социального развития городской инфраструктуры, он представляет собой крупную составную часть единого комплекса 
городского хозяйства муниципального образования, развивающаяся в соответствии с целевыми программами. Индикаторы развития потребительского рынка способны представить информацию о состоянии развития городского хозяйства, транспортной инфраструктуры, культурном и образовательном уровне населения. Некоторые исследователи полагают, что показатели динамики движения потребительского рынка могут быть основой принятия решений для инвесторов и способствовать повышению общего уровня доверия со стороны бизнес-сообщества к действиям местных властей.

Как утверждает мэр города Лондона Б. Джонсон проблемы стабилизации и развития потребительского рынка в современных условиях приобретают особую значимость. Это обусловлено, прежде всего, местом и ролью рынка в системе воспроизводства, в обеспечении связи производства и потребления, сбалансированности предложения и спроса. [2, с. 93] Организация развития потребительского рынка в Британской столице учитывает маркетинговые, демографические, финансовые, производственные тенденции и осуществляется в рамках комплексной программы развития, включающей следующие подсистемы:

- рынок продуктовых товаров;

- рынок промышленных товаров бытового назначения;

- рынок коммунальных услуг;

- рынок транспортных услуг;

- рынок информационных услуг.

При мэрии города Лондона функционирует Общественный Совет потребителей, который принимает решения по развитию и корректировке плановых показателей каждого из перечисленных систем потребительского рынка британской столицы. Приоритеты организации развития потребительского рынка города Лондона представлены в таблице 1.

Таблица 1.

Приоритеты организации развития потребительского рынка города Лондона

\begin{tabular}{|c|c|c|}
\hline Наименование подсистемы & Приоритеты развития & Возможности достижения \\
\hline продуктовых & $\begin{array}{l}\text { повышение } \text { экологичности } \\
\text { продуктов питания }{ }^{1}\end{array}$ & $\begin{array}{lr}\text { государственная } & \text { поддержка } \\
\text { фермерских } & \text { хозяйства } \\
\text { Великобритании, } \\
\text { разработка } & \text { стандартов } \\
\text { экологичности } & \text { продуктов } \\
\text { питания } & \end{array}$ \\
\hline $\begin{array}{lr}\text { рынок } & \text { промышленных } \\
\text { товаров } & \text { бытового } \\
\text { назначения } & \\
\end{array}$ & $\begin{array}{l}\text { увеличение объема выпуска } \\
\text { энергосберегающей } \\
\text { продукции }\end{array}$ & $\begin{array}{l}\text { использование } \\
\text { возможностей } \\
\text { возобновляемых } \\
\text { источников энергии }\end{array}$ \\
\hline $\begin{array}{l}\text { рынок } \\
\text { услуг }\end{array}$ & $\begin{array}{ll}\text { использование } & \\
\text { возможностей } & \text { повторной } \\
\text { переработки } & \text { продуктов } \\
\text { коммунальной } & \\
\text { инфраструктуры. }\end{array}$ & $\begin{array}{l}\text { модернизация сооружений } \\
\text { коммунальной } \\
\text { инфраструктуры, } \\
\text { привлечение бизнеса к } \\
\text { формированию } \quad \text { систем }\end{array}$ \\
\hline
\end{tabular}

${ }^{1}$ Согласно правилу, установленному ЕС, экологически чистыми могут продаваться продукты сельскохозяйственного происхождения, чьё сырьё, по крайней мере, на 95 \% производится органически чистым. Добавки в продукции стараются избегать, но использование определенных веществ, оправдано согласно структуре продукта, и чтобы обеспечить его сохранность. Подавляющее большинство пищевых добавок в органически чистых продуктах - это существующие в самой природе соединения. 
Impact Factor $=0.307$ based on International Citation Report (ICR)

\begin{tabular}{|c|c|c|}
\hline & $\begin{array}{lr}\text { Применение } & \text { методов } \\
\text { рециклинга }^{1} \quad \text { в } & \text { развитии } \\
\text { коммунальной }^{\text {инфраструктуры }} & \\
\end{array}$ & $\begin{array}{lll}\text { очистки } & \text { в } & \text { городском } \\
\text { хозяйстве } & & \end{array}$ \\
\hline рынок транспортных услуг & $\begin{array}{lr}\text { снижение } & \text { загруженности } \\
\text { основных } & \text { городских } \\
\text { магистралей, } & \text { снижение } \\
\text { негативного } & \text { воздействия } \\
\text { транспорта } & \text { на } \\
\text { среду } & \text { городскую }\end{array}$ & \begin{tabular}{lr} 
Дальнейшее & \multicolumn{2}{c}{ продвижение } \\
программы по развитию \\
велосипедного движения в \\
центре \\
Реализация проектов и \\
программ по развитию эко \\
логичного \\
железнодорожного \\
скоростного транспорта
\end{tabular} \\
\hline
\end{tabular}

Общественный Совет при мэре города Лондона также контролирует систему организации продвижение товара до конечного потребителя. Следует учитывать, что продвижения материального продукта (например, продовольственного товара) оценивается членами Общественного Совета как по ассортименту сопровождающих продажу услуг, так и по технологии работы с клиентами.

Следует отметить, что в последние четыре года структура потребностей населения города Лондона, факторов, формирующих спрос на услуги, также качественно изменились. В настоящее время отмечается рост объема личного потребления, качественные изменения в его структуре, расширение доли потребностей, удовлетворяемых за счет различного рода услуг социального назначения. При этом влияние экономических факторов на сферу услуг обуславливается общей динамикой валового внутреннего продукта, изменением спроса на потребительские товары, уровнем занятости и уровнем доходов населения, состоянием госбюджета. [5, с. 130]

Органы управления столицей Великобритании для выработки политики регулирования развития потребительского рынка на локальных территориях используют показатели дифференциация доходов по отдельным социальнодемографическим группам. Информационной базой для анализа социального расслоения по доходам на уровне отдельной территории в целом служит статистика домашних хозяйств. Обследование проводится статистическими органами на основе квотной выборки по возрасту, полу, составу семьи, источникам средств существования, месту проживания и т.д. Контроль изменений показателей осуществляется один раз в год. Для сравнения - в большинстве муниципальных образований Российской Федерации статистической информации на уровне муниципальных образований, необходимой для оценки социального расслоения и принятия обоснованных решений по развитию потребительского рынка, нет. Вместе с тем подобная статистика позволяет проанализировать доходы различных социально-демографических групп населения, оценку населением своих доходов и своего материального положения по сравнению с окружающими, потребительские настроения населения, изменения в стиле потребительского поведения, слабые стороны потребительского рынка и т.д. [1, с. 24]

Полученные экспертным сообществом данные публикуются в открытом доступе на порталах муниципалитетов города Лондона. Это позволяет производителям товаров и услуг корректировать ценовую политику, объемы предложения, что способствует

1 Под рециклингом понимают переработку отходов каким-либо способом с получением материалов, продуктов или изделий, пригодных к повторному использованию

2 В Лондоне одна из развитых сетей велопроката в Европе. В столице Великобритании насчитывается 6000 велосипедов, велопоездка до получаса бесплатная. 
гармонизации и дальнейшему развитию перспективных направлений потребительского рынка. Одним из таких направлений выступает сфера производства биопродуктов ${ }^{1}$. Представители общественности города активно продвигают инициативу поддержки и субсидирования торговых точек, которые специализируются на продаже экологически чистых продуктов. Городские власти предоставляют льготы бизнесу, который осуществяет продажу экологических чистых продуктов питания. В результате все возрастающего спроса на данный вид продукции, а также благодаря поддержке местных властей в Лондоне растет количество торговых точек, которые предлагают полную продуктовую линейку экологически чистых продуктов питания. Биостандарты в таком магазине действуют на все, в том числе на упаковку. Цены здесь отличались от цен в обычном супермаркете в среднем где-то на 15-20\%. Опрос, проведенный Ассоциацией по изучению потребительского спроса Великобритании, еще в 2012 году показал, что 74\% населения Лондона постоянно или время от времени покупают какието продукты, а также напитки, косметику, средства личной гигиены, детские и другие товары под марками «био» или «эко». [10, с. 1281; 3, с. 249]

Для сравнения в Берлине в среднем на органическую еду его жители тратят 84 евро в месяц. В Австрии, по данным соцопросов, биопродукты покупают примерно 72\% населения. В Испании, где соотношение цены и качества продуктов одно из самых лучших в Европе, спрос на биотовары также растет. Во всех крупных сетевых супермаркетах обязательно есть соответствующие отделы. Экологически чистые фрукты и овощи обычно лежат в овощных развалах, но отдельно, обозначенные зелеными этикетками. Многие мадридцы и жители других городов страны покупают продукты, мед, травяные чаи, витамины и БАДы в специализированных экомагазинах сети Hierbolario. Во Франции четверо из десяти жителей страны, как выяснили социологи, хотя бы раз в жизни пробовали биопродукты. Здесь, как и в Испании, производят биовино, в которое не попадает ни сахар, ни красители, ни биодобавки. Емкости для вина обрабатывают водой, очищенной кислородом. Несмотря на высокую стоимость, французы активно покупают органическую еду, а также косметику, текстиль, детские товары, одежду, обувь и мебель. [9, с. 163]

Однако в столице Великобритании городские власти поддерживают не только торговые компании, осуществляющие продажи биопродуктов, мэрия города предоставляет льготы владельцам биомагазином, но и биокафе 2 .

Реализация программы по поддержке торговых компаний, продающих экологически чистую продукцию, осуществляется в Лондоне с 2006 года. Представители муниципальной власти и общественности проводят мониторинг влияния потребления экопродуктов на здоровье населения. Отмечается, что граждане, регулярно потребляющие подобные продукты обращаются к врачу в 4 раза реже, чем те, кто не включает в свой рацион эти товары. [7, с. 159; 4, с. 92]

На общегородском уровне властями осуществляется ряд программ и инициатив, направленных на развитие потребительского рынка. Само городское управление представлено многочисленными институтами, призванными поддерживать интересы местных сообществ и бизнеса. На уровне муниципалитетов, или как в Лондоне их называют «бороу», ведется свое управление: существует глава (мэр) района и его администрация, в каждом районе есть департамент, отвечающий за развитие потребительского рынка в рамках района. Следует отметить, что у каждого района Лондона есть свой сайт в Интернете, где можно найти

\footnotetext{
${ }^{1}$ Ежегодный рост мирового рынка биопродуктов составляет 20\%

${ }^{2}$ Стоимость большинства экологически чистых продуктов в Европе в 2-2,5 раза выше стоимости обычных, в России же разница в ценах иногда доходит до тысячи процентов.
} 
информацию о составе и динамике развития потребительского рынка того или иного района, а на некоторых даже пожаловаться на ущемление прав или недостаточный уровень обслуживания. В функции мэра входит разработка плана развития потребительского рынка, в частности его роль в поддержании баланса интересов представителей общественности, бизнеса и власти. Мэр Лондона всегда принимает весомое участие в обсуждении проблем развития потребительских рынков, и дает начало важнейшим инициативам.

\section{References:}

1. Беляевский И.К. Демографический маркетинг: наука и практика // Вопросы статистики.- 2010. - №4. - С. 24-34

2. Борис Джонсон - мэр Лондона//Муниципальная служба. 2013. № 2 (62). С. 92-98.

3. Воронин Г.А., Лапин В.А., Широков А.Н. Основы управления муниципальным хозяйством. М.: Моск. обществ. научн. фонд. 2010.

4. Макдональд, Малкольм. Стратегическое планирование маркетинга: Процесс планирования маркетинга. Роль эксперт. компьютер. систем. Методы, структуры и рамки маркетинга. Орг. и человеч. фактор. Долгосрочные цели маркетинга / [Пер. с англ. М. Бугаева]. - СПб. : Питер, 2011. - 266с.

5. Международные экономические отношения: учебник / под ред. В.Е. Рыбалкина. - М.:Юнити-Дана, 2012

6. Организация управления и самоуправления в крупнейших городах: современное состояние и проблемы: учеб. пособие / Под ред. проф. В.Б. Зотова - М: ЮгоВосток-Сервис, 2006.

7. Рагулина Ю.В., Нечаева О.А. Понятие и сущность комплексного социальноэкономического развития муниципальных образований. Объединение экономистов и правоведов - ключ к новому этапу развития=The unification of economists and lawyers - is a key to the new stage of development сборник научных работ Международного научно-практического конгресса. 2013. С. 158-161.

8. Guy, C.M. Corporate strategies in food retailing and their local impacts: a case study of Cardiff // Environment a. planning. A. - L., 2009. - Vol. 28, N 9. - P. 1575-1602.

9. Ragulina Y.V., Musayev R.R., Elesina M.V. The analysis of foreign practice of territory development on the basis of the implementation of national projects. Наука и технологии. 2013. Т. 1. С. 157-166.

10. Sivitanidou, R. Warehouse and distribution facilities and community attributes: an empirical study // Environment a. planning. A. - L., 2010. - Vol. 28, N 7. - P. 1261-1278 Bibliogr.: p. 1277-1278. 